International Journal of English Literature and Social Sciences
Vol-6, Issue-5; Sep-Oct, 2021

Peer-Reviewed Journal

\title{
Science Teachers' Understanding of Higher Order Thinking Skills
}

\author{
Karma Cheda ${ }^{1}$, Karma Utha ${ }^{2}$
}

${ }^{1}$ Bartsham Central School, Trashigang Dzongkhag, Ministry of Education, Bhutan.

${ }^{2}$ Samtse College of Education, Royal University of Bhutan, Bhutan.

Received: 01 Sep 2021; Received in revised form: 04 Oct 2021; Accepted: 11 Oct 2021; Available online: 19 Oct 2021

(C2021 The Author(s). Published by Infogain Publication. This is an open access article under the CC BY license

(https://creativecommons.org/licenses/by/4.0/).

\begin{abstract}
For students to become critical, creative, and engage in problem solving, teachers' role is critical. A teacher is required to implement higher order thinking skills activities in the class. The study focused on science teachers' understanding of higher order thinking skills (HOTS) in teaching and learning science. A mixed methods approach was adopted for the study. Data collected from survey questionnaires, classroom observation, interviews and documents analysis were analysed based on descriptive statistics and thematic analysis. A total of 14 teachers participated in the study. The findings showed that most of the science teachers have clear understanding of HOTS. Further, implementation of HOTs requires activity-based teaching approach but approaches used were mostly lecture method with a few group discussion and clarification of doubts in teaching science. Some of the challenges teachers face in implementing HOTS were time constraint, language barrier and terminologies used in science textbooks currently in use in schools. The study recommends teachers to use appropriate activity-based teaching approach to implement HOTs activities. It is also recommended to carry out a study to find the correlation between HOTS and academic performance of students.
\end{abstract}

Keywords - Higher order thinking skill, implementation, strategies, conceptual understanding.

\section{INTRODUCITON}

Benjamin Bloom's six levels of thinking: remembering, comprehending, applying, analysing, evaluating, and creating is to make students aware of types of learning and to evaluate whether meaningful learning is there or not [1,2]. According to Mainali [3], the first three thinking are of lower order convergent level and the remaining are of higher order divergent level. The convergent level requires basic recalling and understanding, while, divergent level requires critical and creative thinking. The Higher Order Thinking Skills (HOTS) is a concept based on Bloom's higher thinking levels.

Science is one of the subjects offered from class IX onwards in Bhutanese secondary schools. The current science curriculum for class IX was revised and implemented in 2016 and for class X in 2017. The revision was mainly to improve the learning outcomes of students by promoting higher thinking skills. The textbooks consist of more hands-on activities that requires student centered learning to be practiced. According to Rabgay [4], to promote imaginative, critical and creative skills in students, teachers need to focus more on student-centered learning. Teachers need to practice their teaching based on everyday life activities which develop critical thinking skills. However, the teaching in Bhutan is still dominated by teacher [5] and whether it helps to develop HOTs in students is a concern. Further, the students are required to carry out project work and homework that may require accessing weblinks that are provided in the textbooks. These weblinks are supposed to promotes HOTS. But how far these weblinks are accessed is another concern as students hardly have any access to internet facilities in schools [6].

A study conducted by Bhutan Council for Secondary Examination and Assessment [BCSEA] (2019) stated that 
schools should strengthen and enhance Competency Based (CB) activities that require HOTS and assessment in the curriculum. As such, the CB questions which promote higher level thinking is introduced mostly in written examination. According to Cheki [7], at the primary level, 5\% CB questions was introduced in 2011 and at secondary level $30 \%$ was introduced in 2017. At the secondary level, it was introduced as part of Bhutan Council for Secondary Examination (BCSE), which is a board examination for all class $\mathrm{X}$ students. The percentage reflected is supposed to increase gradually over years. According to Gurung [8], the $\mathrm{CB}$ question is not simply on the ability to recall information or use of formulae or procedures but requires to focus on specific problems and situations that students need to resolve and apply on what they have learned that requires HOTS. The CB questions make use of HOTS. But teachers have difficulty in setting CB questions and focus on setting lower order thinking (LOT) questions (researchers' personal experience of working in school).

Hence, the purpose of the study is to find out Science teachers conceptual understanding of HOTs and whether they have the required skills to carryout HOTS activities in teaching Science.

\section{LITERATURE REVIEW}

Understanding the conceptual meaning of HOTS by teachers is very important as they are implementers in the classroom. There are many definitions of HOTS given by different authors. Thomas and Thorne [9] defined HOTS as a level that is higher than remembering facts or telling something back to someone precisely the way it had been told by teachers. Similarly, HOTS is the thinking that is taking place in the higher levels of the hierarchy of cognitive processing [10]. Further, Heong et al. (2011) defined HOTS as the expanded use of the mind to meet challenges. Furthermore, HOTS is the ability to understand and interpret objects, events, and phenomena as a whole by using their own language construction [11], Nugroho \& Suryadarma, 2018.

Implementation of HOTS in teaching Science by teachers play an important role for academic performances as well in generating students' creativity and critical thinking skills. According to Retnawati et al. [12], teachers' knowledge about HOTS and its teaching and learning techniques are key to successful education. The findings of Sinelnikov et al. [13] and Pratama and Retnawati [14] showed that the growth in teachers' content knowledge on HOTS leads to a better understanding of teaching and learning of the subject which ultimately improves students' performance. The outcome from students' HOTS development can be achieved by the active role of teachers in planning, implementing, and evaluating HOTS oriented learning [12].

Similarly, Bhutan Professional Standards for Teachers [15] indicated teachers' mastery of content knowledge, understanding the curriculum, and ability to make subject matter meaningful to learners as one of the standards. When teachers possess content knowledge, teachers would know how to segregate HOTS activities from the Science textbook and prepare learning activities on HOTS. A study conducted by Eraikhuemen and Ogumogu [16] in Nigeria on assessment of the conceptual understanding of force and motion of secondary school Physics teachers in the EDO South Senatorial District found that teachers have low conceptual understanding of Physics concepts and that teachers are likely to pass on what they know to their pupils. This suggests that teachers need to understand the concepts of HOTS in terms of content. The consequences of not having a proper understanding and comprehension of HOTS lead to an inability to master higher level thought and an inability to design and execute appropriate guidance during teaching and learning sessions [17].

In this $21^{\text {st }}$ century, one critical aspect in improving effective teaching and learning Science by students is to examine the effectiveness of teachers in developing students' capability to think while ensuring class activities [18]. It is shown that school are now invited to shift the focus from syllabus to learning results. According to Ngussa and Lyimo [19], the world is shifting from knowledge based to effective learning methods that engage learners to specific skills to execute tasks. In the implementation of learning, HOTS cannot be directly taught to students, instead students should be trained about HOTS as a skill through learning activities that support its development [12].

Teachers, as role models, have to apply diverse teaching methods such as, relevant movies, interesting stories, newspaper articles, scientific articles, hand-on experiments, and individual or group assignments. When teachers ask higher order questions and encourage explanations such as, why; what; how; what if; how do they compare; or what is the evidence, they are helping their students to develop important critical thinking skills [10,Adedoyin, 2010; [20]. It is revealed that the success or failure of carrying out Science activities depend a great deal on teachers since they are the main actors to put the activities into practices [21].

To implement and teach higher order thinking skills (HOTS) to students in the classroom setting for some reasons is found to be difficult. According to Juhansar et al. [22], firstly, higher order thinking skills require extra works and efforts; second to implement them need much 
time; third, Physics teacher should have deeper practical understanding, and fourth, to implement HOTS, teacher need to employ a number of strategies and practices in different contexts and situation. Zohar and Dori, [23] support that teachers were confused as stimulating higher order thinking is appropriate only for high achieving students whereas low achieving students were unable to deal with such tasks that require HOTS and such tasks generated frustration in the students. Further, the study conducted by Seman et al [17] on teachers' challenges in teaching and learning for higher order thinking skills (HOTS) in primary school in Malaysia found that due to heavy curriculum content and lack of time, teachers' face challenging to plan lesson that can achieve HOTS objectives as well as content objective. On the issue of the syllabus, teachers were required to complete it before the final examination. This indicated that the teaching and learning were still very much exam oriented as opposed to applying HOTS in teaching and learning Science.

\section{METHODS}

The study employed a mixed methods approach to gain an insight on teachers' conceptual understanding and practices of HOTS activities in teaching Science. The quantitative data was collected through the use of survey questionnaires from the Science teachers. To supplement the survey data and get a deep understanding, qualitative data was collected through semi-structure interview with select Science teachers. Classroom observations was also carried out. As part of document analysis, a study of class IX Physics textbooks and mid-term questions papers were carried out.

The research was conducted in one of the eastern Dzongkhags in Bhutan. A total of four secondary schools that has classes IX-XII were involved in the study. All the science teachers were included in the survey.

A random sampling was used to select teachers for the interview. A total of 14 teachers participated in the interviews (Physics: 6, Chemistry- 4, Biology-4). 4 classroom observation was carried out in order to gain deeper understanding on implementation of HOTS activities in classroom teaching.

\section{RESULTS}

The survey data was analysed using Statistical Package for Social Sciences (SPSS 22). The features like Mean, Standard deviation, and tables were used to interpret the data. The study used descriptive analysis of quantitative data. The mean and standard deviation were calculated based on frequency of occurrences adapted from Joy and Ventayen [24] as in Table1.

For the qualitative data, the interviews were recorded and transcribed. In-depth study of the interview transcripts was undertaken. In addition, document analysis on the activities of class IX Physics textbook, analysis of midterm questions papers from one of the schools was undertaken. Also, classroom observation notes were studied in depth to understand the practice of HOTS by the teachers. To maintain participants' anonymity, T1, T2 ... is used to refer to each of the teacher-interviewees.

The study of the survey data, interviews and document analysis resulted in the following themes:

\section{Teachers understanding on HOTS \\ Implementation of HOTS in classroom teaching}

Strategies implemented by teachers in teaching HOTS

Challenges faced by teachers in implementing HOTS activities

Each of the theme is discussed in the following sections.

\subsection{Teachers Conceptual Understand on HOTS}

Table 2 showed the overall average mean of $M=3.90$ with standard deviation $S D=0.66$ indicating teachers' high agreement on the conceptual understanding on HOTS activities. Among the statements, HOTS activities are given in new science textbook was rated the highest ( $M=$ 4.27; $S D=0.46$ ) showing that the textbooks had included HOTS activities. Further, Questions provided in the textbook have given hints for students to answer $(M=3.60$; $S D=0.87)$ meaning that clues were given to support students in answering the questions. Also, the examples given in the textbooks were found to be relevant $(M=4.10$; $S D=0.68)$.

The interview with teachers also showed that teachers understood the HOTS activities. According to a teacher, the activities helped students to enhance their creating, application, analyzing and evaluating skills (T5). Another teacher $\mathrm{T} 2$ said that

HOTS activities are the task that demand the students to deploy stringent thinking process. ... HOTS in terms of Science means that students are able to understand the content and give logical reasoning and think about new things and reasons.

Table 1. Interpretation of the scale values 


\begin{tabular}{lllll}
\hline Scale & Range & Frequency of occurrence & Level of Severity & \\
\hline 5 & $4.21-5.00$ & Strongly agree & Always & Highest \\
4 & $3.41-4.20$ & Agree & Very often & High \\
3 & $2.61-3.40$ & Neutral & Neutral & Moderate \\
2 & $1.81-2.60$ & Disagree & Often & Low \\
1 & $1.00-1.80$ & Strongly disagree & Never & Lowest \\
\hline
\end{tabular}

Table 2. Conceptual Understanding on HOTS activities from Science textbook

\begin{tabular}{lllll}
\hline Sl no. & Statements & M & SD & Level of severity \\
\hline 1 & HOTS activities are given in new Science textbook & 4.27 & 0.46 & Highest \\
\hline 2 & $\begin{array}{l}\text { The examples given in the textbook are all relevant to students' } \\
\text { level }\end{array}$ & 4.10 & 0.68 & High \\
\hline 3 & New textbook has clear information without ambiguity & 3.63 & 0.63 & High \\
\hline 4 & $\begin{array}{l}\text { Questions provided in the textbook have given hints for students } \\
\text { to answer }\end{array}$ & 3.60 & 0.87 & High \\
\hline & Total & $\mathbf{3 . 9 0}$ & $\mathbf{0 . 6 6}$ & High \\
\hline
\end{tabular}

Furthermore, T13 stated "It is learning which involved the critical thinking, evaluation and creation of new things after the learning the concept from class. It's much different from rote learning". Similar views were expressed by $\mathrm{T} 7$ and $\mathrm{T} 12$.

However, a teacher seemed to have difficulty in understanding what HOTS mean. According to the teacher, "I don't know what HOTS is. Hearing for first time. It is not there in syllabus nor in teachers' guidelines or code of conduct" (T1). Another teacher T6 also seemed to have some misunderstanding on what HOTS means. According to T6, HOTS mean teaching from toughest to easiest.

\subsection{Implementation of HOTS in Classroom Teaching}

The Table 3 showed an overall average mean of $M=3.96$ with $S D=1.26$ showing that the teachers had high agreement on the implementation of HOTS in classroom teaching. Among the statements, I prefer HOTS activities teaching methods than traditional methods on teaching was rated the highest with $M=4.21$ and $S D=0.61$ showing teachers preference of HOTS activities. The teachers agreed that they explored for resources to support them in preparing HOTS questions $(\mathrm{M}=4.00 ; \mathrm{SD}=1.20)$. They also spent time in thoroughly checking the students answers to questions on HOTS $(M=3.88 ; S D=2.67)$.

During the interviews, teachers said that they used varied teaching approaches that are activity based (T1, T4, T11) to implement HOTS. According to a teacher,
In teaching science, I used lower order thinking skills (LOTS) first to develop the concepts of any type of topics. After concept is completely disseminated, then I use HOTS to make them aware and clear about the concept (T12).

Similarly, T13 stated,

After teaching the HOTS concepts, I allow them to relate that concept to their daily life. I used some techniques such as DARTS, Quiz, Video tutorial to make the understand more. In terms of LOTS, I allow them to read by themselves and share to their friends.

A teacher T7 also shared that they implemented HOTS through independent learning and research (T7). Though teachers agreed on using different strategies in the class, the class observation found that most of the teachers lecture what was in the textbook. It was also found that most of the teachers used LOTS questions where students already have pre-knowledge. There was hardly any use of HOTS questions. Teachers hardly demonstrate the concepts other than pure explanations using board.

\subsection{Strategies Implemented by Teachers in Teaching HOTS}

Strategies Implemented according to Teacher in Teaching HOTS is as shown in Table 4.

Table 3. HOTS activities implemented in classroom teaching 


\begin{tabular}{|c|c|c|c|c|}
\hline $\begin{array}{l}\text { Sl. } \\
\text { no. }\end{array}$ & Statements & $\mathbf{M}$ & SD & $\begin{array}{l}\text { Level of } \\
\text { severity }\end{array}$ \\
\hline 1 & I always ask HOTS questions in the class to see students' understanding & 3.73 & 0.75 & High \\
\hline 2 & $\begin{array}{l}\text { I explore the internet and other resources on how to prepare HOTS } \\
\text { questions for the students }\end{array}$ & 4.00 & 1.20 & High \\
\hline 3 & $\begin{array}{l}\text { I thoroughly check students' assigned work on how HOTS questions were } \\
\text { answered }\end{array}$ & 3.88 & 2.67 & High \\
\hline 4 & $\begin{array}{l}\text { I prefer HOTS activities teaching methods than traditional methods on } \\
\text { teaching }\end{array}$ & 4.21 & 0.61 & Highest \\
\hline \multirow[t]{2}{*}{5} & $\begin{array}{l}\text { I inform the students on the HOTS questions as they will be expected to } \\
\text { get similar questions in their examination }\end{array}$ & 3.98 & 1.06 & High \\
\hline & Total & 3.96 & 1.26 & High \\
\hline
\end{tabular}

Table 4. Strategies implemented in teaching physics

\begin{tabular}{lllll}
\hline Sl. No & Statements & M & SD & Level of severity \\
\hline 1 & $\begin{array}{l}\text { I provide more HOTS questions in the class to } \\
\text { be solved by students in groups }\end{array}$ & 3.98 & 0.53 & High \\
\hline 2 & $\begin{array}{l}\text { I provide more HOTS questions in the class to } \\
\text { be solved by students individually }\end{array}$ & 3.98 & 0.38 & High \\
\hline 3 & $\begin{array}{l}\text { I thoroughly check students' understanding } \\
\text { on HOTS activities' after providing a task/ } \\
\text { activity }\end{array}$ & 4.10 & 0.63 & High \\
\hline 4 & $\begin{array}{l}\text { I discuss HOTS questions with students when } \\
\text { they have difficulty in solving }\end{array}$ & 4.25 & 0.58 & Highest \\
\hline 5 & $\begin{array}{l}\text { I encourage students to carry out group } \\
\text { presentations on an assigned task }\end{array}$ & 4.15 & 0.53 & High \\
\hline
\end{tabular}

The Table 4 showed the overall average mean of $M=4.09$ with standard deviation $S D=0.53$ indicating the teachers use of varied strategies in teaching HOTS. The statements, I discuss HOTS questions with students when they have difficulty in solving questions was rated the highest with $M=4.25$ and $S D=0.58$ showing that discussion was a predominant practice when students faced difficulty in solving problems. The Table 4 also showed that students were provided opportunity to work in group as well as individually to work on HOTS questions. The practice of group work was evident in the interview data also. For example, T7 stated, "I assign peer helpers and provide support to those struggling". However, in the class observation, although students were asked to work on a problem in groups, all the answers to the problem were provided by the teachers.

The students understanding of the task was given a priority $(M=4.10$ and $S D=0.61)$. The interview data was in line with the survey data. There were cases of teachers either explaining the questions repeatedly till students were clear about it (T9) or explaining with use of examples (T10). Beside other methods were used by teachers to help students understand the task. For instance, a teacher T13 stated, "I used different teaching methods like DARTS, Quiz, discussion, video tutorial to help students understand more efficiently".

Though teachers agreed on using different strategies in the class, the class observation found that most of the teachers lecture what was in the textbook. Teachers hardly demonstrate the concepts. They just using chalk and board.

\subsection{Strategies to Overcome Challenges in Implementing HOTS Activities}

The analysis of teacher's interview revealed that implementing HOTS in classroom teaching has many 
challenges. Some of the challenges faced are: Providing enough time for students; Lack of multiple representations of the concept; difficult to frame the questions; and language competency (T6, T1, T8). Students were also found to get bored and confused while discussing HOTS concepts (T12). Some of the strategies teachers use to overcome the challenges is as reflected in Table 5.

The average mean rating of $M=3.92$ and $S D=0.55$ indicated teachers' high agreement to use of different strategies to overcome any challenges in implementing HOTS activities. The statements, I use teaching learning materials to enhance HOTS and I use ICT to enhance HOTS showed the highest mean of $(\mathrm{M}=4.48 ; \mathrm{SD}=0.67)$ and $(\mathrm{M}=4.31 ; \mathrm{SD}=0.57)$ respectively. This indicated a high use of ICT and teaching learning materials to support HOTS activities in the classroom teaching. The Table 5 also revealed that teachers were very good in using ICT to support their teaching.

Table 5. Strategies in overcoming challenges in implementing HOTS

\begin{tabular}{lllll}
\hline Sl. no & Statements & M & SD & Level of severity \\
\hline 1 & $\begin{array}{l}\text { I use teaching learning materials to } \\
\text { enhance HOTS }\end{array}$ & 4.48 & 0.67 & Highest \\
\hline 2 & I use ICT to enhance HOTS & 4.31 & 0.57 & Highest \\
\hline 3 & $\begin{array}{l}\text { Collection of HOTS resources is easy for } \\
\text { me }\end{array}$ & 3.10 & 0.91 & Moderate \\
\hline 4 & I ask HOTS questions frequently & 3.85 & 0.38 & High \\
\hline 5 & I am very good in using ICT & 3.88 & 0.23 & High \\
\hline
\end{tabular}

\section{DISCUSSION}

The findings in the result section are discussed in line with the present study's research questions and literatures. The discussion used the same themes as reflected in result section.

\subsection{Teachers' Understanding on HOTS}

Teachers' conceptual understanding of HOTS helps in teaching the concept clearly to the students. Students learn best when an example of solving a question is demonstrated to them rather than explicit explanation. From this study, it was found out that Science teachers had good conceptual understanding of HOTS. This helped them in designing HOTS activities. The study also showed that HOTS activities were included in Science textbook and were relevant to students learning. Further, clues were included in the textbook to help students to answer the HOTS questions. According to students, teachers had good knowledge of HOTS and were able to deliver HOTS activities in the class. The studies conducted by Sinelnikow et al. (2015) and Pratama and Retnawati [14] showed that the growth in teachers' content knowledge resulted in better understanding and learning of the subject which ultimately improve students' performance. Therefore, teachers' with good knowledge of HOTS in Science content could design appropriate HOTS activities to provide more learning activities and thinking skills to the students.

It was also found that the teachers could define and explain the HOTS in their own ways. Teachers involved in this study defined HOTS as logical reasoning, applying learned concepts, and to enhance students' creativity, innovation, and analyzing skills. The definition used by teachers was in line with Ramos et al. [10]'s definition wherein they defined HOTS as skills like creative thinking, critical thinking, analysis, problem-solving, and visualization. However, it was found that the teachers do not have a complete understanding of the concept of HOTS based on $21^{\text {st }}$ century skills. According to Scott [25], in $21^{\text {st }}$ century skill, HOTS demand learners to possess innovation skills, life and career skills, and information, media, and technology skills. Teachers involved in this study seemed to be not aware of the skills relating to communication and collaboration as no mention of these were made when asked about their understanding of HOTS.

Further, teachers' misconceptions on HOTS hamper the better understanding of the concept. There were teachers who seemed to be not clear about HOTS. For example, a teacher said that teaching from toughest to easiest was the main concept of HOTS (T6). According to Seman, et al. [17] and Retnawati et al. [12], the lack of proper understanding and comprehension of HOTS lead to an inability to master the skills of HOTS and an inability to 
design and execute appropriate guidance during teaching and learning sessions.

\subsection{Implementation of HOTS in Teaching Science}

The implementation of HOTS in teaching Science is one contributing factor to improve HOTS. The quantitative data analysis from teachers rating found a high average mean. Likewise, the teachers' preference on HOTS activities based teaching methods in the classroom was highest with the mean score of 4.21. To implements HOTS, teachers consistently ask thought provoking HOTS questions, and explore internets and other resources to develop HOTS activities in their lesson. Miri et al. [26] supported that to promote HOTS, teachers need to purposely and persistently deal with real-world problems, encouraging open-ended class discussion, and fostering inquiry-oriented experiment results in a good chance of developing critical thinking capabilities in the class. Similarly, the qualitative data analysis exhibited that teachers implemented HOTS during the delivery of the lesson. This finding aligns with the finding of Mainali [3] who emphasized the need to implement HOTS in classroom teaching and learning process as it is more authentic and relevant to the real world. Furthermore, Afifah and Retnawati [27] stated that when teachers teach by showing learning materials that contain HOTS, it connects the concepts with new concepts and improves students thinking skills. Their findings complement this study's finding whereby teachers stressed the important of using internet and exploring other resources to implements HOTS in teaching Science as such approaches of a teachers enhances students learning.

The use of ICT and other resources to prepare HOTS questions supported teachers to implements HOTS in classroom teaching. This was in line with the finding of Ganapathy et al. [28].

\subsection{Strategies Implemented by Teachers in Teaching HOTS}

The methods of teaching HOTS play a vital role for the students to improve learning HOTS questions in Science. The teachers in this study gave HOTS questions to students to solve individually, as well as through group discussion. Further, they check the clarity of HOTS activities after providing task and also encourage students to do group presentation. Teachers were also found incorporating HOTS in all the lessons to make students to think deeper. This result corroborated with the findings of Saido et al. [29]. Their study on strategies used by secondary science teachers in teaching science in $7^{\text {th }}$ grade in Malaysia, found that applying knowledge such as problem-solving and hands-on activity improves student's higher cognitive skills.

Though teachers in this study agreed to the use of varied strategies in class, the classroom observation revealed lecture method being a predominant practice. The study by Prayitno et al.[30] in Indonesia found that students who were taught HOTS with lecture method as a treatment had the lowest score in HOTS than students who were being treated with other learning strategies. Therefore, teachers' need to use varieties of teaching methods while implementing HOTS activities other than lecture method.

\subsection{Strategies to Overcome Challenges in Implementing HOTS Activities}

There were numerous challenges faced by teachers teaching HOTS. Some of the challenges were time constraint and multiple representation. The finding of this study is in line with the study conducted by Seman et al. [17] in Malaysia. They found that time constraint was the factor that affects the implementation of HOTS in the classroom. Though preparing the HOTS in Physics requires lots of time and multiple representations, Afifah and Retnawati [27] asserted that they have to manage time proportionally and thoroughly to measure students' HOTS in implementing in the classroom.

Language was another challenge faced by the students. The language and terminology given in the textbook were difficult for the students to comprehend and answer the HOTS questions. According to Nagappan [31], to improve the language of students, teachers need to exploit and encompass all the activities in the four language components, i.e., listening, speaking, reading, and writing will promote thinking skills among the students. Similarly, teachers also need to know how to ask questions while teaching because good questioning techniques are useful to attract students' attention when they are less interested or bored in class [27].

\section{CONCLUSION}

The study concluded that most teachers have clear conceptual understanding HOTS. However, few teachers still have misconception on it. Most of the teachers' related HOTs to one of the 21st-century skills.

The HOTS requires hands-on activities and needs to shift from lecture method teaching to activity-based. Out of the many activity-based teaching methods, the study results showed that teachers implemented mostly group discussion and clarifying of doubts on HOTS questions. Other relevant strategies like problem-solving, doing 
activities, hand-on experiences, encouraging open-ended class discussion, and fostering inquiry-orientated experiments to help students to learn more on HOTS activities in the classroom were rarely used. Besides, time constrain, language barrier and terminologies used in the science textbook were some of the challenging teachers faced in implementing HOTS activities.

\section{RECOMMENDATION}

This study provides significant insight into the Science teachers' understanding of Higher Order Thinking Skills. However, there were challenges and difficulties in implementing HOTS activities in the schools. The study recommends teachers to use appropriate activity-based teaching approach to implement HOTs activities. The Teacher Professional Support Division and school management are suggested to organize professional development for teachers on HOTS activities. Further, the study recommends to carry out a study to find the correlation between HOTS and academic performance of students.

\section{COMPETING INTERESTS}

Authors have declared that no competing interests exist.

\section{REFERENCES}

[1] Rahman SA, Manaf NFA. A critical analysis of Bloom's Taxonomy in teaching creative and critical thinking skills in Malaysia through English literature.English Language Teaching. 2017;10(9): 245-256.

Available:http://doi.org/10.5539/elt.v10n9p245

[2] Adams NE. Bloom's taxonomy of cognitive learning objectives. Journal of the Medical Library Association: JMLA. 2015;103(3): 152 .

[3] Available:https://doi.org/10.3163/1536-5050.103.3.010

[4] Mainali BP. Higher order thinking in education. Academic Voices: A Multidisciplinary Journal. 2012;2(1):5-10.

[5] Rabgay T. The effect of using cooperative learning method on tenth grade students' learning achievement and attitude towards Biology. International Journal of Instruction. 2018;11(2):265-280.

[6] Utha K. Formative assessment practices in Bhutanese secondary schools and its impact on quality of education; 2015.

[7] Utha K, Rinzin S. Peer-learning: An alternative teaching pedagogy for highly teacher centered classes. International Journal of English, Literature and Social Science.2019;4(5):1520-1529.

[8] Cheki K. Book your space now: Competency-based assessment to assess students' learning outcomes, Kuenselonline; 2018.
[9] Available:https://kuenselonline.com/competency-basedassessment-to-assess-students-learning-outcomes/

[10] Gurung AK. Use of teachers' reference for competency based assessment: A survey report. BCSEA Journal for Educational Assessment.2015;37.

[11] Thomas A, Thorne G. How to increase higher order thinking. Metarie, LA: Center for Development and Learning; 2009.

[12] Ramos JLS, Dolipas BB, Villamor BB. Higher order thinking skills and academic performance in physics of college students: A regression analysis. International Journal of Innovative Interdisciplinary Research, 2013;4:48-60.

[13] Moran KR, Keeley P. Teaching for conceptual understanding in science. NSTA Press, National Science Teachers Association; 2015.

[14] Retnawati H, Djidu H, Kartianom A, Anazifa RD. Teachers' knowledge about higher-order thinking skills and its learning strategy. Problems of Education in the 21st Century. 2018;76(2):216-230.

[15] Sinelnikov OA, Kim I, Ward P, Curtner-Smith M, Li W. Changing beginning teachers' content knowledge and its effects on student learning. Physical Education and Sport Pedagogy. 2015;21(4):425-440.

[16] Pratama GS, Retnawati H. Urgency of higher order thinking skills (HOTS) content analysis in mathematics textbook. Journal of Physics: Conference Series.2018;1-7.

[17] Available:https://doi.org/10.1088/17426596/1097/1/012147.

[18] BPST. Teachers professional standards for Teachers. Ministry of Education; 2019.

[19] Eraikhuemen L, Ogumogu AE. An assessment of secondary school physics teachers' conceptual understanding on force and motion in EDO in South Senatorial district. Academic Research Internal.2014;5(1):253-261.

[20] Seman SC, Yusoff WMW, Embong R. Teachers challenges in teaching and learning for higher order thinking skills (HOTS) in primary school. International Journal of Asian Social Science. 2017; 7(7):534-545.

[21] Yen TS, Halili SH. Effective teaching of higher order thinking (HOT) in education. The Online Journal of Distance Education and e-Learning. 2015;3(2):41-47.

[22] Ngussa BM, Lyimo NS. Correlation between code change strategy, teaching modalities and learners' competencebased abilities: A case of Arusha Technical College, Tanzania. International Journal of Educational Policy Research and Review.2019;6(3):54-62.

[23] Tekene LM. Enhancing teachers' questioning skills to improve children's learning and thinking in Pacific Island Early Childhood Centres. New Zealand Journal of Teachers' Work.2006;3(1):12-23.

[24] Kapucu S, Yildirim U. Physics teachers' behavioral, control and normative beliefs about teaching physics according to the national high school physics curriculum in Turkey. International Journal of Environmental and Science Education. 2014; 9(2): 133-157. Available: https://doi.org/10.12973/ijese.2014.207a 
[25] Juhansar J, Karim S, Pabbajah M. The implementation of higher order thinking skills at universitas Teknologi Yogyakarta in Indonesia: Opportunities and challenges. Proceedings of the International Conference on Education and Higher Order Thinking Skills.2018;80-90.

[26] Zohar A, Dori YJ. Higher order thinking skills and lowachieving students: Are they mutually exclusive? The Journal of the Learning Sciences. 2003;12(2):145-181.

[27] Joy CC, Ventayen RJM. Role of social media in education: A teachers' perspective. ASEAN Journal of Open and Distance Learning. 2017;9(2).

[28] Scott LA. 21st century skills early learning framework. Partnership for 21st Century Skill (P21); 2017.

[29] Available:http://www.p21.org/storage/documents/EarlyLea rning_Framework/P21_ELF_Framework_Final.pdf

[30] Miri B, David BC, Uri Z. Purposely teaching for the promotion of higher-order thinking skills: A case of critical thinking. Research in Science Education.2007;37(4):353369. Available:https://doi.org/10.1007/s11165-006-9029-2

[31] Afifah IRN, Retnawati H. Is it difficult to teach higher order thinking skills? Journal of Physics: Conference Series IOP Publishing, India; 2019.

[32] Ganapathy M, Singh MKM, Kaur S, Kit LW. Promoting higher order thinking skills via teaching practices. $3 \mathrm{~L}$ : Language, Linguistics, Literature. 2017;23(1).

[33] Saido GA, Siraj S, Nordin AB, Al-Amedy OS. Teaching strategies for promoting higher order thinking skills: A case of secondary science teachers. Malaysian online Journal of Educational Management.2015;34(4):1630.Available:https://www.researchgate.net/publication/321 423244

[34] Prayitno, B. A., \& Suciati, T. (2018). Enhancing students' higher order thinking skills in science through Instad strategy. Journal of Baltic Science Education, 17(6), 10461055.

[35] Nagappan R. Language teaching and the enhancement of higher-order thinking skills. Anthology Series-SEAMEO Regional Language Centre.2001;190-223. 